\title{
Gene Action for Determining Yield and Quality Attributing Traits in Brinjal (Solanum melongena L.)
}

\author{
P.K. Yadav ${ }^{1}$, S.D. Warade ${ }^{2}$, Mukul Kumar ${ }^{3 *}$, Siddhartha Singh ${ }^{4}$ and A.K. Pandey \\ ${ }^{1}$ Indian Institute of Vegetable Research, Varanasi-221305, Uttar Pradesh, India \\ ${ }^{2}$ Department of Vegetable Science, ${ }^{3}$ Department of Plant Breeding and Genetics, \\ ${ }^{4}$ Department of Basic Sciences and Humanities, College of Horticulture and Forestry, Central \\ Agricultural University, Pasighat-791102, Arunachal Pradesh, India \\ ${ }^{5}$ College of Horticulture and Forestry, Central Agricultural University, Pasighat-791102, \\ Arunachal Pradesh, India \\ *Corresponding author
}

\section{A B S T R A C T}

A field experiment was conducted to evaluate the $28 \mathrm{~F}_{1}$ hybrids derived from $8 \times 8$ half diallel fashion along with eight parents in randomized block design with three replications

\section{Keywords}

Solanum

melongena,

Yield and Quality

parameters,

Gene action,

Diallel.

Article Info

Accepted:

21 May 2017

Available Online:

10 June 2017 during winter season at Vegetable experimental farm, College of Horticulture and Forestry, Central Agricultural University, Pasighat, Arunachal. The genetic components of variation were determined for eleven characters viz., plant height, number of branches per plant, days to first flowering, fruit length, fruit girth, fruit yield per plant, solasodine content, total phenol content and anthocyanin content. The genetic components $\hat{\mathrm{D}}, \hat{\mathrm{H}}_{1}$ and $\hat{\mathrm{H}}_{2}$ were significant for number of branches per plant, days to first flowering, days to first fruit harvest, fruit girth, number of seeds per fruit and anthocyanin content indicating the importance of both additive and dominant gene effects in regulating these traits. However, higher value of $\hat{H}_{1}$ and $\hat{H}_{2}$ compared to $\hat{D}$ for all traits except fruit length, significance value of $h^{2}$ for fruit length, fruit yield and total phenol, average degree of dominance $\left(\hat{H}_{1} / \hat{D}\right)^{1 / 2}$ and ratio of $\mathrm{KD} / \mathrm{KR}$ for yield and other traits including quality parameters showed the preponderance of dominance genes in the expression of and hence, suggested that hybrid breeding can be used efficiently to improve yield together with quality traits in brinjal.

\section{Introduction}

Brinjal (Solanum melongena L.) also known as eggplant is an important solanaceous vegetable crop grown round the year in India mainly grown for its immature, unripe fruits which are used in various ways as cooked vegetable. It is popular among people of all social strata and hence, it is rightly called as vegetable of masses (Patel and Sarnaik,
2004). Brinjal is considered to have originated in Indo-Myanmar region (Vavilov, 1928) as it posses marked diversity. According to Zeven and Zhukovsky (1975) it originated in India and have secondary center of variation in China. In India most of the local varieties which are grown by the cultivators have not been fully utilized in any genetic 
improvement programme. The development of cultivars with improved fruit yield and quality for better market value, through breeding has received relatively little attention in vegetable especially in eggplant. For the improvement of brinjal, one needs to elucidate the genetic nature and magnitude of quantitatively inherited traits and estimate prepotency of parents in combinations.

The information generated in the process can be used to understand the magnitude of heterosis. However, genetic control of different yield and quality related as well as agronomic traits has been studies extensively (Sidhu et al., 1980 and Chadha et al., 1990) in eggplant.

The direct selection for quality traits in eggplant, same as in all other crops, will not be successful due to interaction of many genes with environment.

Knowledge of the genetic controlling system of the character to be selected and genetic variation are the pre-requisite for viable breeding strategy.

Therefore, the present study entitled Gene action studies for yield and quality attributing traits in Brinjal (Solanum melongena L.) is undertaken to understand the nature of gene effects involved in the expression of a character in interacting and non-interacting crosses. An assessment of these genetic parameters will allow for the development of efficient breeding strategies for eggplant cultivar improvement.

\section{Materials and Methods}

The eight most promising and diverse genotypes viz., Swarna Pratibha, NDB-3, Pant Rituraj, Pusa Purple Long, BR-112, CHFB-6, CHFB-7 and CHFB-8 were crossed in $8 \times 8$ half diallel fashion during February to March, 2015. The resulted $28 \quad F_{1}$ hybrids combinations and eight parents were evaluated in randomized block design with three replications during winter season of 2015 at Vegetable experimental farm, College of Horticulture and Forestry, Central Agricultural University, Pasighat, Arunachal Pradesh which is located between $28^{\circ} 04^{\prime} \mathrm{N}$ latitude and $95^{\circ} 22^{\circ} \mathrm{E}$ longitude at an elevation of 153 meters above the mean sea level.

The 35 days old seedlings of each cross and parents were transplanted in rows spaced at $60 \mathrm{~cm}$ with plant to plant spacing of $45 \mathrm{~cm}$ apart. All the recommended package and practices was followed to grow a successful crop. Observations were recorded on five randomly selected plants from each genotype in each replication for eight quantitative characters namely, plant height $(\mathrm{cm})$, number of branches per plant, days to first flowering, days to first fruit harvest, fruit length $(\mathrm{cm})$, fruit girth $(\mathrm{cm})$, number of seeds per fruit and fruit yield per plant $(\mathrm{kg})$. Among qualitative traits, Solasodine alkaloids $(\mathrm{mg} / 100 \mathrm{~g})$ content was calculated as per procedure adopted by Bajaj et al., (1979). The total phenol (mg/100g) was estimated the method given by Malick and Singh (1980) with the Folinciocalteau reagent. Anthocyanin content (mg/100g) was found out as per method suggested by Fuleki and Francis (1986). The mean values of each genotype were subjected to analysis of variance. The estimation of genetic components of variation was calculated for the analysis of numerical approach followed the method given by Hayman (1954).

\section{Results and Discussion}

In the present study, the estimates of genetic components of variance (Table 1) revealed that additive $(\hat{\mathrm{D}})$ and dominance $\left(\hat{\mathrm{H}}_{1}\right.$ and $\left.\hat{\mathrm{H}}_{2}\right)$ components were significant and positive for number of branches per plant, days to first flowering, days to first fruit harvest, fruit length, fruit girth, number of seeds per fruit 
and anthocyanin content which indicated the both additive and dominance gene action conditions in expression of these characters and was similar to findings of Dhameliya and Dobariya (2009). Further, estimates of higher and significant dominance components of variance $\left(\hat{\mathrm{H}}_{1}\right.$ and $\left.\hat{\mathrm{H}}_{2}\right)$ than additive genetic variance $(\hat{D})$ again confirmed the dominance gene action and dominant genes were also in the favorable direction for expression of these characters except fruit length.

Tha et al., (2006) and Monpara and Kamani (2007) and Thangavel et al., (2011) also reported involvement of non-additive gene action in the inheritance of yield and yield related traits. However, the plant height, fruit yield per plant, solasodine content and total phenol content exhibited non-significant and low estimate of $\hat{\mathrm{D}}$ in comparison to $\hat{\mathrm{H}}_{1}$ and $\hat{\mathrm{H}}_{2}$ confirmed the predominant effect of dominance gene action for expression of these characters. Similar results for plant height were also reported by Kumar et al., (2011) and Deshmukh et al., (2014).

Further, the estimates of additive genotypic variance $(\hat{D})$ was lower in magnitude than dominant components $\left(\hat{\mathrm{H}}_{1}\right.$ and $\left.\hat{\mathrm{H}}_{2}\right)$ of genotypic variance for all the traits except fruit length which showed preponderance of dominance effects in the expression of fruit yield and its attributes and governed by dominance type of gene action. Tha et al., (2006), Monpara and Kamani (2007) and Thangavel et al., (2011) also reported involvement of non-additive gene action in the inheritance of yield and yield related traits. The estimates of $\hat{\mathrm{H}}_{1}$ and $\hat{\mathrm{H}}_{2}$ were unequal for plant height, days to first flowering, days to first fruit harvest, fruit length, number of seeds per fruit, solasodine content, total phenol and anthocyanin content indicating thereby unbalanced distribution of dominance and recessive alleles while almost similar estimates of these two components showed balanced distribution of both dominant and recessive alleles in case of number of branches per plant, fruit girth and fruit yield per plant.

However, the positive and significant estimates of both $\hat{\mathrm{H}}_{2}$ and $\hat{\mathrm{H}}_{1}$ reflected the effects of dominance gene in favourable as well as positive direction for all the traits under studied. Similar trends were also confirmed by Kumar et al., (2011) and Deshmukh et al., (2014) in brinjal.

The $\hat{\mathrm{F}}$ value was positive for plant height, number of branches per plant, days to first flowering, days to first fruit harvest, fruit length, number of seeds per fruit, solasodine content, total phenol content and anthocyanin content which showed that dominance alleles are more frequent than recessive alleles in parents. On the other hand, the negative estimates of $\hat{F}$ were observed for fruit girth and fruit yield per plant indicated that recessive alleles are more prevalent than dominant alleles.

Asymmetrical distribution of dominance and recessive genes in parents for various traits were also observed by Tha et al., (2006), Monpara and Kamani (2007), Thangavel et al., (2011) and Deshmukh et al., (2014). Significance value of $h^{2}$ for fruit length, fruit yield per plant, number of seeds per fruit and total phenol content revealed the important effect of heterozygous loci in expression of these traits. The average degree of dominance $\left(\hat{\mathrm{H}}_{1} / \hat{\mathrm{D}}\right)$ $1 / 2$ involved in the action of genes was observed greater than unity for all the traits except fruit length. This indicated that presence of overdominance for these traits and therefore, it is suggested that heterosis breeding might be advantageous for improvement of yield and its attributing traits in brinjal. These findings are in conformity with those of Kumar et al., (2011), Bhattacharya et al., (2013) and Deshmukh et al., (2014). 
Table.1 Estimates of genetic components of variation and their ratio for eleven characters in brinjal

\begin{tabular}{|c|c|c|c|c|c|c|c|c|c|c|c|}
\hline $\begin{array}{l}\text { Components } \\
\text { of variation }\end{array}$ & $\begin{array}{c}\text { Plant } \\
\text { height } \\
\text { (cm) }\end{array}$ & $\begin{array}{c}\text { Number of } \\
\text { branches } \\
\text { per plant }\end{array}$ & $\begin{array}{l}\text { Days to } \\
\text { first } \\
\text { flowering }\end{array}$ & $\begin{array}{c}\text { Days to } \\
\text { first fruit } \\
\text { harvest }\end{array}$ & $\begin{array}{c}\text { Fruit } \\
\text { length } \\
\text { (cm) }\end{array}$ & $\begin{array}{l}\text { Fruit } \\
\text { girth } \\
(\mathrm{cm})\end{array}$ & $\begin{array}{l}\text { Number of } \\
\text { seeds per } \\
\text { fruit }\end{array}$ & $\begin{array}{c}\text { Fruit yield } \\
\text { per plant } \\
\quad(\mathrm{kg})\end{array}$ & $\begin{array}{c}\text { Solasodine } \\
\text { content } \\
(\mathrm{mg} / \mathbf{1 0 0 g})\end{array}$ & $\begin{array}{c}\text { Total } \\
\text { phenol } \\
\text { content } \\
(\mathrm{mg} / \mathbf{1 0 0 g})\end{array}$ & $\begin{array}{c}\text { Anthocyanin } \\
\text { content } \\
(\mathrm{mg} / \mathbf{1 0 0 g})\end{array}$ \\
\hline$\hat{\mathrm{H}}_{1}$ & $\begin{array}{l}81.14 * * \\
\pm 21.64\end{array}$ & $\begin{array}{l}4.85 * * \\
\pm 0.71\end{array}$ & $\begin{array}{l}50.45 * * \\
\pm 13.35\end{array}$ & $\begin{array}{c}56.53 * * \pm \\
15.06\end{array}$ & $\begin{array}{c}23.78 * * \\
\pm 5.40\end{array}$ & $\begin{array}{l}3.39 * * \\
\pm 1.13\end{array}$ & $\begin{array}{c}160889.90 * * \\
\pm 40861.48\end{array}$ & $\begin{array}{l}2.52 * * \\
\pm 0.55\end{array}$ & $\begin{array}{l}1.41 * * \\
\pm 0.43\end{array}$ & $\begin{array}{c}3500.12 * * \\
\pm 644.71\end{array}$ & $\begin{array}{c}28683.83 * * \\
\pm 7158.69\end{array}$ \\
\hline$\hat{\mathrm{H}}_{2}$ & $\begin{array}{l}70.32 * * \\
\pm 18.83\end{array}$ & $\begin{array}{l}4.25 * * \\
\pm 0.61\end{array}$ & $\begin{array}{l}36.05 * * \\
\pm 11.61\end{array}$ & $\begin{array}{c}40.28 * * \pm \\
13.11\end{array}$ & $\begin{array}{c}17.81 * * \\
\pm 4.69\end{array}$ & $\begin{array}{l}3.30 * * \\
\pm 0.98\end{array}$ & $\begin{array}{c}128040.40 * * \\
\pm 35549.46\end{array}$ & $\begin{array}{l}2.32 * * \\
\pm 0.48\end{array}$ & $\begin{array}{l}1.09 * * \\
\pm 0.38\end{array}$ & $\begin{array}{c}2843.98 * * \\
\pm 560.90\end{array}$ & $\begin{array}{c}22989.30 * * \\
\pm 6228.06\end{array}$ \\
\hline$\hat{\mathrm{F}}$ & $\begin{array}{c}19.08 \\
\pm 22.24\end{array}$ & $\begin{array}{l}1.20 \\
\pm 0.72\end{array}$ & $\begin{array}{r}15.33 \\
\pm 13.72\end{array}$ & $\begin{array}{c}16.01 \pm \\
15.48\end{array}$ & $\begin{array}{l}9.23 \\
\pm 5.55\end{array}$ & $\begin{array}{l}-0.38 \\
\pm 1.16\end{array}$ & $\begin{array}{c}5979.91 \\
\pm 42000.05\end{array}$ & $\begin{array}{l}-0.33 \\
\pm 0.57\end{array}$ & $\begin{array}{c}0.01 \\
\pm 0.45\end{array}$ & $\begin{array}{c}40.37 \\
\pm 662.68\end{array}$ & $\begin{array}{r}10928.96 \\
\pm 7358.16\end{array}$ \\
\hline$\hat{\mathrm{h}}^{2}$ & $\begin{array}{r}1.27 \\
\pm 12.62\end{array}$ & $\begin{array}{l}-0.05 \\
\pm 0.41\end{array}$ & $\begin{array}{l}-3.86 \\
\pm 7.79\end{array}$ & $\begin{array}{c}-3.97 \pm \\
8.79\end{array}$ & $\begin{array}{l}9.53 * * \\
\pm 3.15\end{array}$ & $\begin{array}{l}0.59 \\
\pm 0.66\end{array}$ & $\begin{array}{l}95640.39 * * \\
\pm 23840.97\end{array}$ & $\begin{array}{l}2.55 * * \\
\pm 0.32\end{array}$ & $\begin{array}{c}0.13 \\
\pm 0.25\end{array}$ & $\begin{array}{c}1032.35^{*} \pm \\
376.16\end{array}$ & $\begin{array}{c}2961.34 \\
\pm 4176.80\end{array}$ \\
\hline$\hat{\mathrm{E}}$ & $\begin{array}{l}8.91 * * \\
\pm 3.13\end{array}$ & $\begin{array}{l}0.64 * * \\
\pm 0.10\end{array}$ & $\begin{array}{l}8.93 * * \\
\pm 1.93\end{array}$ & $\begin{array}{c}9.23 * * \pm \\
2.18\end{array}$ & $\begin{array}{c}0.42 \\
\pm 0.78\end{array}$ & $\begin{array}{c}0.04 \\
\pm 0.16\end{array}$ & $\begin{array}{c}858.68 \\
\pm 5924.91\end{array}$ & $\begin{array}{c}0.03 \\
\pm 0.08\end{array}$ & $\begin{array}{c}0.00 \\
\pm 0.06\end{array}$ & $\begin{array}{c}2.09 \\
\pm 93.48\end{array}$ & $\begin{array}{c}9.64 \\
\pm 1038.01\end{array}$ \\
\hline$\left(\hat{\mathrm{H}}_{1} / \hat{\mathrm{D}}\right)^{1 / 2}$ & 2.56 & 1.89 & 1.60 & 1.66 & 0.89 & 1.06 & 2.02 & 2.69 & 7.64 & 4.43 & 1.38 \\
\hline$\left(\hat{\mathrm{H}}_{2} / \boldsymbol{4} \hat{\mathrm{H}}_{1}\right)$ & 0.21 & 0.21 & 0.17 & 0.18 & 0.18 & 0.24 & 0.20 & 0.23 & 0.19 & 0.20 & 0.20 \\
\hline$(\mathrm{KD} / \mathrm{KR})$ & 1.86 & 1.61 & 1.64 & 1.61 & 1.42 & 0.88 & 1.08 & 0.69 & 1.10 & 1.05 & 1.71 \\
\hline$\left(\hat{\mathrm{h}}^{2} / \hat{\mathrm{H}}_{2}\right)$ & 0.018 & -0.01 & -0.10 & -0.09 & 0.53 & 0.18 & 0.75 & 1.09 & 0.12 & 0.36 & 0.12 \\
\hline
\end{tabular}

*, ** significant at 5 and 1 per cent probability level, respectively

$\mathrm{KD} / \mathrm{KR}=\left(4 \hat{\mathrm{D}}_{1} \hat{\mathrm{H}}^{1 / 2}+\hat{\mathrm{F}} /\left(4 \hat{\mathrm{D}} \hat{\mathrm{H}}_{1}\right)^{1 / 2}-\hat{\mathrm{F}}\right.$ 
The $\hat{\mathrm{H}}_{2} / 4 \hat{\mathrm{H}}_{1}$ estimate was not equal to 0.25 for all the traits except fruit girth confirmed the asymmetrical distribution of dominance and recessive genes among parents as also observed in the estimate of $\hat{\mathrm{F}}$.

This was in general accordance with the finding of Deshmukh et al., (2014). The ratio of dominant and recessive alleles (KD/KR) i.e. $\left[\left(4 \hat{\mathrm{D}}_{1}\right)^{1 / 2}+\hat{\mathrm{F}} /\left(4 \hat{\mathrm{D}}_{\mathrm{H}_{1}}\right)^{1 / 2}-\hat{\mathrm{F}}\right]$ was observed more than unity for plant height, number of branches per plant, days to first flowering, days to first fruit harvest, fruit length, number of seeds per fruit, solasodine content, total phenol content and anthocyanin content showed the majority of dominant alleles and minority of recessive alleles among the parental strain for these characters.

The higher of proportion of dominant genes observed for most of the characters are in agreement with the findings of Tha et al., (2006), Dhameliya and Dobariya (2009) and Deshmukh et al., (2014). The value of $\hat{\mathbf{h}}^{2} / \hat{\mathrm{H}}_{2}$ was less than unity for all the characters including quality traits except fruit yield per plant reflected the one major gene group involved for most of the characters, which may be due to conceding effects of dominate genes with positive and negative effect, which nullify the effects of each other. These findings are in agreement with Tha et al., (2006) and Kumar et al., (2011) for fruit yield and fruit weight in brinjal.

In the present study, genetic components $\hat{\mathrm{D}}$, $\hat{\mathrm{H}}_{1}$ and $\hat{\mathrm{H}}_{2}$ were significant for number of branches per plant, days to first flowering, days to first fruit harvest, fruit length, fruit girth, number of seeds per fruit and anthocyanin content indicating the importance of both additive and dominant gene effects in regulating these traits. However, higher estimate value of $\hat{\mathrm{H}}_{1}$ and $\hat{\mathrm{H}}_{2}$ compared to $\hat{\mathrm{D}}$ for all the traits except fruit lenth showed that nonadditive gene effect have a greater role than additive gene effects. The positive estimate of dominance components ( $\hat{\mathrm{H}}_{1}$ and $\left.\hat{\mathrm{H}}_{2}\right)$ also suggest that the dominance genes were in the favourable and positive direction for all the traits. The significance value of $h^{2}$ for fruit length, fruit yield per plant, fruit yield per plant, number of seeds per fruit and total phenol content showed the importance of heterozygous loci for dominance effect in the expression of all these traits. The average degree of dominance $\left(\hat{\mathrm{H}}_{1} / \hat{\mathrm{D}}\right)^{1 / 2}$ over all loci was more than unity for all the traits except fruit length suggesting the prevalence of over-dominance. The ratio of $\mathrm{KD} / \mathrm{KR}$ was more than unity for all of the traits along with quality traits except fruit girth and fruit yield per plant signifying the excess of dominant genes than recessive among the parents. Therefore, the present study showed preponderance of dominance genes in the expression of yield and other traits including quality parameters suggesting that hybrid breeding can be used efficiently to improve yield together with quality traits in brinjal.

\section{References}

Bajaj, K.L., Kaur, G. and Chadha, M.L. 1979. Glycoalkaloid content and other chemical constituents of fruits of some eggplant (Solanum melongena L.) varieties. J. Plant Foods, 3(3): 163-168.

Chadha, M.L., Joshi, A.K. and Ghai, T.R. 1990. Heterosis breeding in brinjal. Indian J. Hort., 47: 417-423.

Deshmukh, S.B., Sawant, S.N., Narkhede, G.W. and Dod, V.N. 2014. Gene action studies in brinjal (Solanum melongena). Middle-East J. Sci. Res., 21(11): 21772181.

Dhameliya, H.R. and Dobariya, K.L. 2009. Gene effects for fruit yield and its components in brinjal (Solanum 
melongena L.). Crop Improvement, 36(1): 73-76.

Fuleki, T. and Francis, F.J. 1986. Quantitative methods for anthocyanin: Extraction and Determination of total anthocyanin in cranberries. J. Food Sci., 33: 72-77.

Hayman, B.I. 1954. The theory and analysis of diallel crosses. Genetics, 39: 789809.

Kumar, A., Kumar, S. and Yadav, Y.C. 2011. Gene action studies in brinjal (Solanum melongena L.). Environ. Ecol., 29(4): 1717-1719.

Malick, C.P. and Singh, M.B. 1980. In Plant Enzymology and Histoenzymology, Kalyani Publishers, New Delhi, p. 286.

Monpara, B.A. and Kamani, J.M. 2007. Components of variation and associations among yield attributing traits in segregating populations of brinjal. National J. Plant Improvement, 9(2): 106-110.

Patel, K.K. and Sarnaik, D.A. 2004. Coefficient and path coefficient analysis in brinjal. Haryana J. Hort. Sci., 33: 246-247.

Sidhu, A.S., Bhutani, G.D., Kalloo, G. and Singh, G.P. 1980. Gentics of yield components in brinjal (Solanum melongena L.). Haryana J. Hort. Sci., 9(3-4): 161-164.

Tha, Y.S., Kathiria, K.B. and Srinivas, T. 2006. Combining ability studies over seasons in brinjal (Solanum melongena L.). SAARC J. Agri., 4: 123-133.

Thangavel, P., Thirugnanakumar, S., Saravanan, K.R. and Kumar, N.S. 2011. Gene action for fruit yield and its component characters in brinjal (Solanum melongena L.). Plant Arch., 11(1): 263-265.

Vavilov, N.I. 1928. Geographical centers of our cultivated plants In: Proceedings of 5th International Congress of Genetics, New York, pp. 342-369

Zeven, A.C. and Zhukovsky, P.M. 1975. Dictionary of cultivated plants and their centers of diversity, Wageningen, Netherlands, p. 219.

\section{How to cite this article:}

Yadav, P.K., S.D. Warade, Mukul Kumar, Siddhartha Singh and Pandey, A.K. 2017. Gene Action for Determining Yield and Quality Attributing Traits in Brinjal (Solanum melongena L.). Int.J.Curr.Microbiol.App.Sci. 6(6): 1475-1480. doi: https://doi.org/10.20546/ijcmas.2017.606.173 